\title{
IMPROVED SYSTEM OF ADAPTATION OF MOTOR TRANSPORT FOR OPERATION IN EXTREMELY LOW-TEMPERATURE AREAS
}

\author{
Egorova Tatyana Polikarpovna \\ Leading Researcher, Scientific-Research Institute of \\ Regional Economy of the North \\ North-Eastern Federal University \\ Yakutsk, Russian Federation \\ 677000, Yakutsk, Lenin Ave., 1
}

Abstract- The goal of research is to develop a conceptual solution of the problem of transport vehicle adaptation to operation in the north and arctic regions of the Republic Sakha of (Yakutia) and to establish a business system to make the area more accessible for vehicles. Methodology and research technique are based on theories proposed by both national and foreign scientists and researchers, who addressed the issues of transport system development in the north regions, technological forecasting, innovation management and economic analysis. Efforts to adapt standard models of vehicles for operation under Arctic conditions and to introduce cross-country transport machines have unraveled a number of challenging issues in the complex cycle of developing a vehicle and delivering it to consumer. One of the problems derives from Technical Regulations introduced in 2015, which prescribe strict rules regarding changes to vehicles' design, making it almost impossible to legitimately modify and improve standard models to adapt them for Arctic conditions. Lack of systematic support from certification and development tests of vehicles utilized under Arctic conditions is the reason behind such flaws in the regulations. The present paper contains a conceptual solution to this problem and describes an established business system for shaping an infrastructure for certification and development tests of transport vehicles for operation in Arctic conditions. Characteristic properties of the transport system adopted in the arctic zone of the Republic Sakha of (Yakutia) that condition adaptation measures for vehicles are analyzed. Vehicles adjusted for Arctic and brought to the national market are reviewed. The novelty of the present study consists in developing a mechanism of shaping an infrastructure for certification and development tests of vehicles for operation in the arctic zone of the Republic Sakha of (Yakutia), as well as establishing a foundation for taking necessary measures directly in the Republic Sakha of (Yakutia). The authors defined a task of mathematical and economic modeling of a vehicle choice to substantiate sponsorship claim of interregional transportation in arctic regions from all budget levels.

\author{
Delakhova Anna Mikhailovna \\ Senior Researcher, Scientific-Research Institute of Regional \\ Economy of the North \\ North-Eastern Federal University \\ Yakutsk, Russian Federation \\ 677000, Yakutsk, Lenin Ave., 1
}

Keywords- Arctic, accessibility by transport, crosscountry vehicles, snowmobile, ice roads, seasonality, climate

\section{INTRODUCTION}

Arctic zone of the republic is a place where transport service is the hardest to provide. Natural transportation lines (rivers and seas) and temporary roads referred to as ice roads are used in the arctic zone of the Republic Sakha (Yakutia) (hereafter Yakutia) to transport goods and people. In the context of road impassibility and season-related functioning of main means of transportation, their stable operation and adaptation to severe environment are crucially important. In 16 hard-to-reach areas of Yakutia, 70\% of socially significant passenger transportation are arranged using helicopters, which travel by 86 routes, where no alternative transport service is available. In certain populated localities air transport service is inaccessible due to poor technical characteristics of runway systems of airports. Motor vehicles are the only option to use for passenger and goods inland transportation within the region during winter season. Apart from severe and changeable weather, which hinders with regular and reliable transportation service, other issues also restrict transport operation, namely: large distances, low freight and passenger traffic flow, season-related character of road usage, and high cost of fuel.

From technical and organizational points of view, maintaining stable operation of the transport system in the arctic zone of Yakutia remains the most difficult and costly task associated with multiple risks. Successful development of these regions will be ultimately governed by the state of transport infrastructure and efforts to modernize it with regard to current trends of improvement of transport systems and logistics, as well as vehicle fleet replacement using units with technical features adapted for operation under natural climatic conditions of Arctic regions.

\section{Methodology AND RESEARCH TECHNIQUE}

\section{A. The goal of research}

The goal of research is to develop a conceptual solution to the problem of vehicle adaptation for operation in the north 
and arctic regions of Yakutia and to establish a business system to make the area more accessible by vehicles.

The set goal determines main research tasks, including:

1) study of characteristic properties of transport system adopted in the arctic zone of the Republic Sakha of (Yakutia) that condition adaptation measures for vehicles;

2) analysis of theoretical and methodological aspects of establishing transport infrastructure adapted to operate under Arctic conditions;

3) review of vehicles adjusted for Arctic conditions and presented on the national market;

4) establishing recommendations and a business system to shape an infrastructure for certification and development tests of transport vehicles for operation in the arctic zone of Yakutia.

\section{B. Methodology}

Methodology and research technique are based on theories proposed by both national and foreign scientists and researchers, who addressed the issues of transport system development in the north regions, technological forecasting, innovation management, and economic analysis. The main methodological approach of the present research involves creating a comprehensive strategy that would ensure the most efficient and complete scientific inquiry to help solve the stated problems. Research tools include general scientific methods of qualitative, comparative, and structural analysis and synthesis, as well as elements of the binning method.

Over $60 \%$ of Russia's territory is located in the Arctic zone and areas equal to it. Yakutia is one of the largest regions of Russia, located in the northeast of the country. Comparative analysis of transport systems of North regions of Russia has indicated unique and singular nature of transport system of Yakutia due to its large territory, a large share of seasonrelated communication routes, and inaccessible transportation lines in north and arctic regions.

Tundra zone and tundra forest belt with numerous rivers form the territory of Yakutian arctic zone. Harsh climate and perennially frozen rock significantly influence increasing costs of construction of transport infrastructure facilities. Region's transport system that accommodates natural resource producers, power providers, housing and utilities infrastructure, and facilities of social services in the arctic zone of the republic is based on the following:

- a network of river and sea routes with developed infrastructure;

- $\quad$ a network of motor roads and ice roads;

- a network of airports, airdromes and helicopter pads.

\section{MAJOR COMPONENTS OF TRANSPORT SYSTEM OF THE ARCTIC ZONE OF THE REPUBLIC SAKHA OF (YAKUTIA)}

\section{A. Arctic transport system in Yakutia}

Wide use of ice roads is specific of the arctic zone of Yakutia (table 1). These roads, though functioning only seasonally (service period is over eight months), could yet be considered regular roads (communication through which could be resumed). Some of them are counted as territorial roads, including the following: Udachny - Olenyok - YuryungKhaya (Anabar), Topolinoye - Batagay - Ust-Kuyga Deputatsky - Belaya Gora (Yana). Motor roads (ice roads) in the arctic zone are isolated; there are no roads between settlements within districts where the distances between populated localities vary from 70 to $450 \mathrm{~km}$.

Current condition and development level of seasonal motor roads are significantly behind modern requirements: there is no cellular signal, re-fuelling stations and maintenance points are few, special-purpose machines are short, and there is no spare parts supply system. Maintenance of ice roads involves considerable expense, including the following: siting and ice measurement, relocation of road machinery using helicopters, signing, cut-off of tracing ruts and filling the holes, dispersing deicing agent onto ascents and descents, and so on.

TABLE I. BASIC ELEMENTS OF THE TRANSPORT SYSTEM IN ARCTIC ZONE OF THE REPUBLIC SAKHA OF (YAKUTIA)

\begin{tabular}{|c|c|c|c|c|}
\hline \multirow[t]{2}{*}{ District } & \multicolumn{3}{|c|}{$\begin{array}{l}\text { Extent of transport } \\
\text { ways, } \mathbf{k m}\end{array}$} & \multirow[b]{2}{*}{ 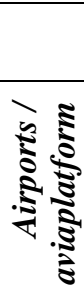 } \\
\hline & 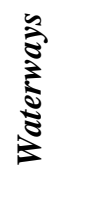 & 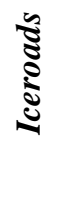 & 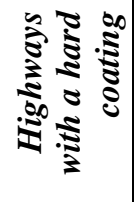 & \\
\hline Abyysky & 591 & 773 & 20 & $1 / 4$ \\
\hline Allaikhovsky & 423 & 612 & 11 & $1 / 4$ \\
\hline Anabar & 224 & 339 & 34 & $1 / 3$ \\
\hline Bulunsky & 1010 & 1676 & 10 & $1 / 8$ \\
\hline $\begin{array}{l}\text { Verkhnekolyms } \\
\text { ky }\end{array}$ & 220 & 409 & 73 & $1 / 3$ \\
\hline Verkhoyansk & 508 & 1855 & 244 & $1 / 10$ \\
\hline Zhigansky & 466 & 391 & 3 & $1 / 3$ \\
\hline Momsky & 150 & 1175 & 53 & $1 / 5$ \\
\hline $\begin{array}{l}\text { Nizhnekolymsk } \\
\text { y }\end{array}$ & 317 & 647 & 14 & $1 / 2$ \\
\hline Oleneksky & 0 & 1133 & 40 & $1 / 2$ \\
\hline $\begin{array}{l}\text { Srednekolymsk } \\
\text { y }\end{array}$ & 528 & 1163 & 40 & $1 / 10$ \\
\hline Ust-Yansky & 383 & 1679 & 257 & $2 / 5$ \\
\hline $\begin{array}{l}\text { Eveno- } \\
\text { Bytantaysky }\end{array}$ & 0 & 538 & 35 & $1 / 2$ \\
\hline
\end{tabular}


According to the report of the Russian meteorological service, Roshydromet, there has been a rise of average annual temperatures in Arctic regions in autumn seasons throughout the past decade (figure 1). This temperature shift delays freeze-up of the arctic rivers and hinders ice strength improvement, which allows for heavy-duty machinery passage, thus shortening operational lifetime of ice roads.

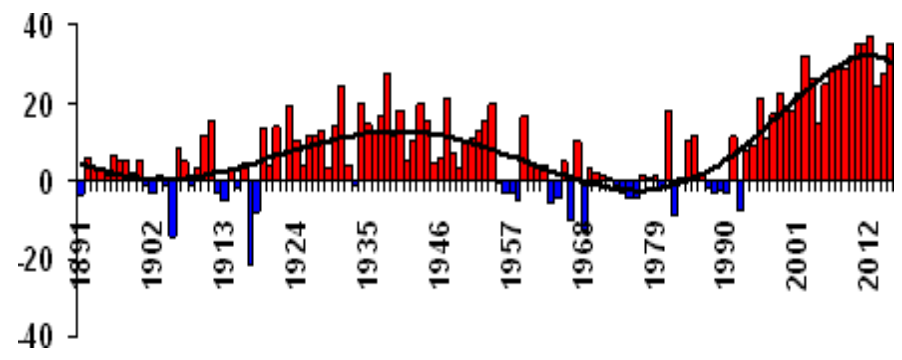

Fig.1. Anomalies of average air temperatures in the Arctic in the fall of 1891-2015

\section{B. Information on life-time of ice roads in the arctic regions of Yakutia}

TABLE II. DATA ON PERIODS OF VALIDITY OF ICEROADS ON THE ARCTIC DISTRICTS OF RS (YA)

\begin{tabular}{|c|c|c|c|c|c|}
\hline \multirow{2}{*}{$\begin{array}{l}\text { Name of } \\
\text { the } \\
\text { iceroad }\end{array}$} & \multirow{2}{*}{$\begin{array}{l}2009- \\
2010\end{array}$} & \multirow{2}{*}{$\begin{array}{l}2015- \\
2016\end{array}$} & \multirow{2}{*}{$\begin{array}{l}\text { 2016- } \\
2017\end{array}$} & \multicolumn{2}{|c|}{ digression } \\
\hline & & & & days & $\%$ \\
\hline Anabar & 151 & 152 & 105 & 46 & $30 \%$ \\
\hline Arctic & 121 & 90 & 90 & 31 & $26 \%$ \\
\hline Yana & 124 & 86 & 85 & 63 & $43 \%$ \\
\hline Indigir & 116 & 70 & 90 & 46 & $40 \%$ \\
\hline $\begin{array}{l}\text { Verkhoya } \\
\text { nye }\end{array}$ & 154 & 86 & 116 & 68 & $44 \%$ \\
\hline
\end{tabular}

Opening of ice roads is a vitally important event for the arctic regions of Yakutia, where volumes of delivered goods are planned for two years ahead. Analysis of service periods of seasonal roads during winter seasons of 2010-2016 has shown significant changes (table 2): 22 to $43 \%$ reduction of roads' service life. As is known, goods are supplied to the arctic regions of Yakutia within limited periods, when annual scope of products for the public, social services, and other consumers of fuel, equipment and food products are delivered, including volumes of goods for maintaining carryover reserve stocks level. If service period of ice roads shortens while the amount of necessary products increases, there appears much concern about expanding the fleet of road freight transport, which could be adapted for operation under low-temperature climate conditions of the Arctic and adjusted using extra design solutions that are aimed at improvement of transportation safety of passengers and goods.

\section{RESEARCH RESULTS AND DISCUSSION}

Ground transport vehicles play a more important role in the Arctic than in the other regions of the country. However, modern cross-country vehicles, produced locally or abroad, designed for operation in extremely low temperature environment are close to nonexistent.
Winter season lasts for 6-8 months in severe natural climatic conditions of the Extreme North. Strong winds, atmosphere pressure surges and snow cover that remains for 89 months are typical for these regions. Huge daily temperature swings $\left(25-30^{\circ} \mathrm{C}\right)$ combined with high relative humidity cause heavy fogs while the temperature is below negative $40^{\circ} \mathrm{C}$, which obscures visibility and complicates vehicle operation.

Efforts to adapt standard vehicles for operation under Arctic conditions have evolved into a separate discipline, which is based on the concepts of mathematical statistics theory, probability theory, fracture mechanics, reliability theory, technology of design and repair of machine components and elements, as well as on development of techniques for repair and restoring vehicles to working condition. Unique road and climate conditions of Arctic and lack of specialized standard models of motor vehicles define the need for putting into operation cross-country vehicles adjusted for operation under Arctic conditions.

A draft of a State program for Social and Economic Development of Arctic Zone of the Russian Federation up to 2020 includes a sub-program for Development of Wheeled and Crawler Machines Production for Extreme Natural Climatic Conditions of Arctic up to 2020. The sub-program makes provisions for development and certification tests for 9 projects of different all-terrain vehicles, their assemblies and component parts, including those developed for the Sakha Republic (Yakutia).

Experiments and best practice of motor vehicle operation under climate conditions of the Arctic region show that performance indicators of most standard models degrade at temperatures below zero. When temperature reaches negative $40^{\circ} \mathrm{C}$ many vehicle models fail.

Today, the owners of freight vehicles solve the problems of adaptation and improvement of serviceability of machines under Arctic conditions on their own. The following improvements and design modifications of standard models of motor vehicles are performed for adaptation to climate conditions of the Arctic:

$$
\begin{array}{ll}
\text { - } & \text { double glazing; } \\
\text { - } & \text { engine compartment winterizing; } \\
\text { - } & \text { added interior heating (Webasto); } \\
\text { - } & \text { boot for heat insulation of the engine from } \\
\text { below; } & \text { winterizing walls of vehicle cab; } \\
\text { - } & \text { installation of additional fuel tanks; } \\
\text { - } & \text { installation of air collector above vehicle } \\
\text { cab; } & \text { installation of waste gas exhaust pipe } \\
\text { pointing upwards. }
\end{array}
$$

The amount of such modifications varies and, in general, depends on diverse road and climate conditions of districts and 
on target preparation of motor vehicles (industrial transport for mining works, truck transport for long-distance haulage, municipal equipment, vehicles for passenger transportation within residential areas, private vehicles of people and so on).

Technical Regulation of Customs Union [TRCU] on Safety of Wheeled Vehicles has been effective since 2015. However, the requirements of this Technical Regulation fail to consider specifics of the road and climate conditions of the Arctic, and do not allow for lawful long-terms modifications of design solutions performed by the operators. Standard vehicles, which have undergone a conformity assessment procedure, are unfit for service (and unsafe) during winter season in such regions. One of the problems derives from Technical regulations, which prescribe strict rules regarding changes to vehicles' design, making it almost impossible to legitimately modify and improve standard models to adapt them for operation under Arctic conditions. Certified testing laboratories (centers) listed in the Unified Register of Certification Authorities and Testing Laboratories (Centers) of Vehicles should draw a conclusion of preliminary technical examination and safety inspection of a vehicle design after its modification.

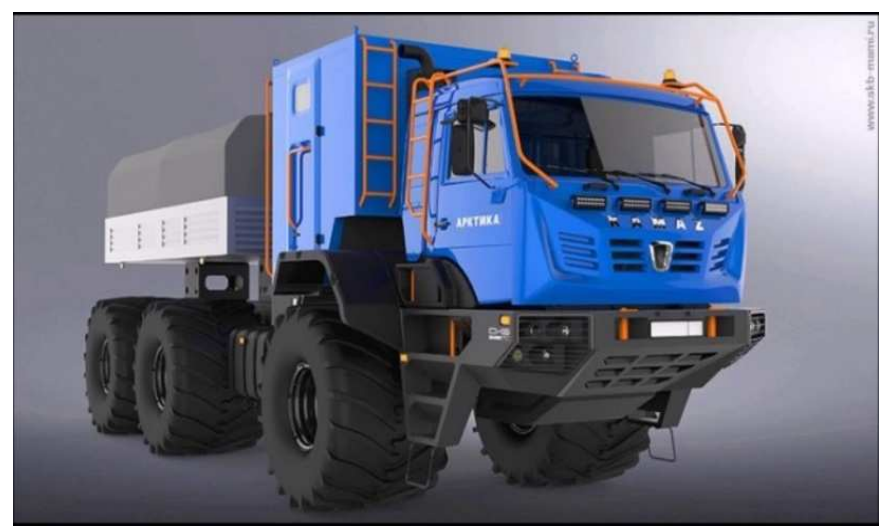

Fig. 2. All-terrain vehicle with mobile house "KamAZ Arctic"

Currently, the largest producers of heavy-duty trucks, such as Kamaz and Ural, introduce standard models with innovative modifications, which are suitable for vehicle operation under road and climate conditions of the Arctic, to the market of special-purpose motor vehicles. For example, a new all-terrain camper van with low-pressure tires KAMAZ-Arctic (figure 2) was introduced at Vuzpromexpo-2017 exposition.

Bryansk Automobile Plant (BAZ), which is a part of the Almaz-Antey holding, developed a new arctic cross-country vehicle designed for Federal Rescue Services operation in the permafrost. Performance trials of new vehicles will be carried out with participation of NEFU in Yakutia in the course of the current year (figure 3 ).

A modification of Ural truck-4320-31 of Motovoz-1 family, model for cold climate designed for operation in the Arctic was introduced on the international military-technical forum Army-2016. A new modified model of Ural-4320 truck adjusted for operation under conditions of Extreme North passed tests in the Arctic (figure 4).
Transport Machines Plant in Nizhny Novgorod (OOO TransMash) produces wheeled snow and swamp-going vehicles with extra-low pressure tires belonging to TTC 3007 Kerzhak and TTC 3901 Unkor families, track snow and swamp-going vehicles of TTC 3401 Vetluga family, as well as other technical transport vehicles [TTC].

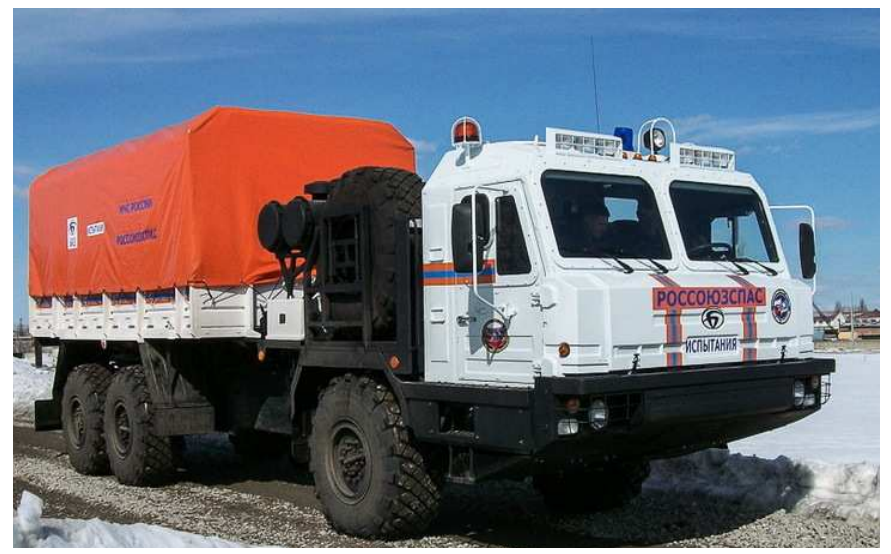

Fig. 3 The Arctic modification of "Voshchina-1" for the Ministry of Emergency Situations

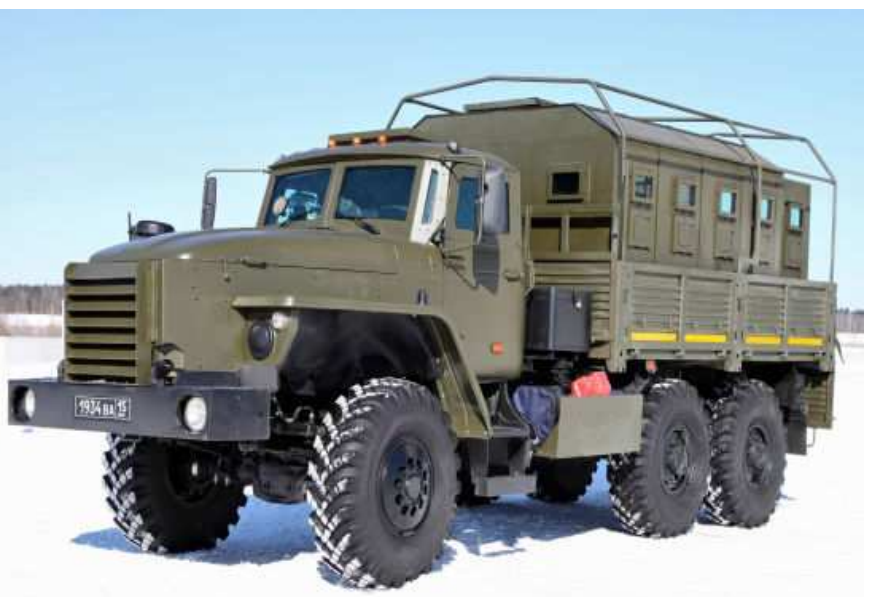

Fig. 4 "Urals-4320" in cold climatic modification

Availability of all-terrain vehicles adapted for operation under Arctic conditions will improve safety of transportation service, promote development of advanced logistic processes in remote and difficult to reach populated localities of the Arctic and stimulate design and construction of vehicles for passenger transportation. Unique engineering solutions in the field of development of all-terrain vehicles for arctic regions are very important. They make arctic regions more accessible by transport and improve mobility of population. The task calls for constant upgrading of vehicle manufacturing process and full range of development and certification testing under natural low-temperature conditions of Yakutia.

While river routes are numerous and while there are no motor roads within the republic, water transportation is in demand. Use of heavy-duty, fuel-saving, large diesel snowmobiles may be best for Arctic conditions. Diesel engine snowmobiles may be used during periods between seasons and in winter. For example, a snowmobile model Aerosani Nerpa 
655 by Siberian Company OOO Aerospetstrans (fig.5) was manufactured using high-strength aluminum alloy resistant to extremely low temperatures. Unlike other models, this snowmobile is fully adapted for operation under Arctic conditions; therefore, it is safe to say that this aerial all-terrain vehicle is suitable for operation in Russia, especially in the north where there are no permanent roads.

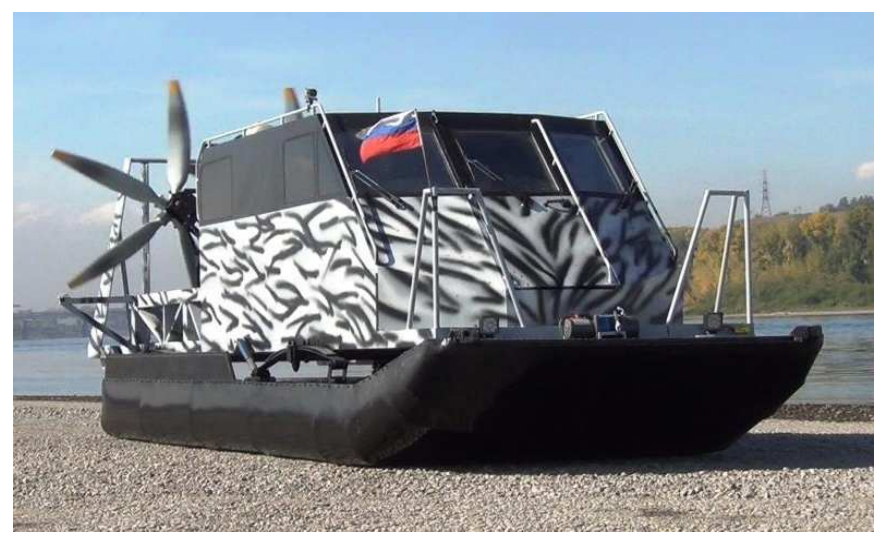

Fig. 5. An amphibian snowmobile "the Seal 655" made by LLC Aerospetstrans

Compared performance features of vehicles used within districts of the republic: helicopters, air-cushion vehicles and snowmobiles (table 3 ). The comparison indicated that the latter are highly competitive. A snowmobile has good acceleration capacity; it could be used all year round to transport small groups of people or goods taking into account that arctic and northern settlements are scarcely populated. Economical operation indicated by the manufacturer predetermines lower costs in comparison with air communication. This is extremely important for population of the arctic regions of Yakutia because of high cost of fuel, which is delivered through an intricate pattern of roads with forced delay of 200-300 days.

Considering that populated localities of arctic regions of Yakutia are very remote, another important advantage of a vehicle is a high-capacity fuel tank $(500 \mathrm{~L})$ that ensures up to 12 hours of travel.

\section{TABLE III. THE COMPARATIVE CHARACTERISTIC OF VEHICLES FOR TRANSPORTATION OF PASSENGERS IN THE ARCTIC ZONE}

\begin{tabular}{|c|c|c|c|}
\hline \multirow{4}{*}{ Indicators } & \multicolumn{3}{|c|}{ Types of vehicles } \\
\cline { 2 - 4 } & $\begin{array}{c}\text { North } \\
\text { Victoria } \\
\text { Amphibian } \\
\text { Amowmobile } \\
\text { "Seal-655" } \\
\text { ous } \\
\text { hovercra } \\
\text { ft }\end{array}$ & $\begin{array}{c}\text { Helicopter } \\
\text { MI-8 }\end{array}$ \\
\hline Manufacturer & LLC & LLC & "the \\
& Aerospetstra & Mil \\
& ns & $\begin{array}{c}\text { Amfibiy } \\
\text { ny } \\
\text { equipme } \\
\text { nt" }\end{array}$ & $\begin{array}{c}\text { Helicopter } \\
\text { Plant }\end{array}$ \\
& & $6,5 / 5,4 / 1$ & $25 / 5,54 / 21$, \\
& &, 9 & 3 \\
\hline $\begin{array}{c}\text { Dimensions, } \mathrm{m} \\
\text { (length/width/he }\end{array}$ & $8,7 / 2,45 / 2,5$ & 5 & \multicolumn{2}{|c}{} \\
\hline
\end{tabular}

\begin{tabular}{|c|c|c|c|}
\hline ight) & & & \\
\hline Power, p/a & 300 & 450 & 3000 \\
\hline $\begin{array}{c}\text { Capacity of a } \\
\text { tank, } 1 .\end{array}$ & $300-500$ & 380 & 3500 \\
\hline $\begin{array}{c}\text { Number of } \\
\text { seats, persons. }\end{array}$ & $8-10$ & 4 & 28 \\
\hline $\begin{array}{c}\text { Mass of } \\
\text { payload, kg. }\end{array}$ & 1100 & $400-600$ & 4000 \\
\hline $\begin{array}{c}\text { Fuel } \\
\text { consumption on } \\
100 \mathrm{~km}, 1 / \\
100 \mathrm{~km}\end{array}$ & $10-15$ & $18-22$ & 288 \\
\hline $\begin{array}{c}\text { Maximum } \\
\text { speed, } \mathrm{km} / \mathrm{h}\end{array}$ & & & 250 \\
\hline -on water & 75 & 90 & \\
\hline $\begin{array}{r}\text {-on snow and } \\
\text { ice }\end{array}$ & $\begin{array}{c}\text { more } \\
\text { than130 }\end{array}$ & $\begin{array}{c}\text { more } \\
\text { than } 130\end{array}$ & \\
\hline -on soil & 50 & 80 & \\
\hline $\begin{array}{l}\text { Temperature } \\
\text { condition, } \mathrm{t}\end{array}$ & +30 till -50 & $\begin{array}{c}+30 \text { till }- \\
45\end{array}$ & +40 till -65 \\
\hline $\begin{array}{l}\text { Course range } \\
\text { without } \\
\text { refueling, } \mathrm{km} \text {. }\end{array}$ & 500 & 400 & $550-800$ \\
\hline $\begin{array}{l}\text { Need for the } \\
\text { serving } \\
\text { infrastructure }\end{array}$ & no & no & Yes \\
\hline
\end{tabular}

\section{CONCLUSION}

Improvement of social and economic state of the arctic zone regions requires adoption of coordinated federal and regional policy. Multiple reforms of the transport industry made so far have not produced an optimal organizational form of a transport system operation fit for the arctic conditions. Review of practices applied by foreign countries located in the north (Canada, Finland, the USA, Norway, etc.) helps identify basic areas of government control over the processes of social and economic development and dealing with problems of transport service in northern regions, namely:

- development of different mechanisms of state support;

- $\quad$ advancement of measures for strengthening of income basis of northern regions;

- incorporation of northern territories into nation-wide development programs.

In foreign countries, the most common measures for encouraging economic activity include various tax relief schemes that consist in exemption or relief from taxes (VAT, profits tax, property tax, payments to payroll budget, or for energy products, etc.), credit and subsidy arrangements on favorable terms and support of small- and medium-size business.

In the short-run, transport infrastructure of Yakutian arctic zone should be updated with regard to the following: 
- $\quad$ building a system for vehicle (cargo and passenger) adaptation for operation under Arctic conditions;

$\bullet$
system;

- $\quad$ ensuring safe operation of vehicles and transportation lines;

- $\quad$ arranging stable passenger service accessible for all social groups (support of minimal social transportation standards).

In mid-term perspective, main objectives are considered to be associated with quality changes in living conditions of the population while overall costs for human life support in arctic regions are reduced. Reaching these milestones involves arrangement of reliable transport service in the republic's arctic regions. To provide it, the following should be done within the next ten years:

- $\quad$ shaping of management system for goods delivery on the base of terminal and logistics complexes with affordable and innovative type of means of transport;

- developing a system of flexible tariffs and compensation for travelling expenses both for passenger transportation and haulage using different means of transport;

- $\quad$ improvement of legislative and regulatory framework for subsidizing expenses for transport infrastructure maintenance involving budgets of various levels;

- $\quad$ building a system for putting into operation new types of vehicles adapted for operation under climate conditions of the region (airplanes of general purpose aviation, mixed river-sea-going ships, allpurpose vehicles that do not require special maintenance infrastructure) and developing brand new "game-changing" vehicles for the Arctic.

To ensure transport accessibility and improve the level of transport service of arctic regions of Yakutia, the authors suggest using the tools of public private partnership to perform tests and introduce new means of motor vehicles and other types of transport suitable for Arctic conditions with the budgets of municipal structures, the Sakha Republic (Yakutia) and the Russian Federation. This model of public private partnership may cover various spheres: design, development, carrying out certification and development tests, experimentalindustrial production, and so on. The following means of transport vehicles are fit for adaptation for the Arctic:

\footnotetext{
- ground transport vehicles (all-terrain vehicles);

- snow and swamp-going vehicles (wheeled, track and other types of vehicles);
}

- hybrid transport (amphibious snowmobiles, airboats, ground-effect vehicles, etc.).
Reinstatement of testing as a result of substantial cut of maintenance costs backed up by improved reliability and safety (incl. environmental safety) could dramatically recover the costs of development (restoration) of testing infrastructure on the territory of Yakutia.

Setting a goal for economic and mathematical modeling of transport choice requires certain conditions:

1) Quantitative relation of transport vehicles.

2) Ensuring execution of specified plan of transportation service.

3) Establishing conditions for investment restraint.

4) Limitation of allocated grants for transport vehicle.

5) Limitation of amounts of municipal public funds allocated for purchasing and maintenance of transport vehicles.

6) The sought quantities should be whole, nonnegative numbers.

An objective function consists in maximization of all indicators. While solving the problem, the restrictive conditions could be changed (amount of investments, grants and so on). This problem should be solved separately for each municipal district taking into account geographic position of populated localities, availability of waterways, level of transport infrastructure development, potential freight and passenger flows, and so on.

In section titled "Development of science-driven business services" of the Strategy for Overall Development of Production Forces, Transport System and Energy Industry of the Sakha Republic (Yakutia) up to 2020 (approved by the Government of the Russian Federation on February 8, 2017), it is clearly stated that vehicle experimental test service that was used in 70s and 80s of the past century should be restored specifically for Yakutia. Main objectives of adaptation of new vehicles to the extremely cold conditions of Yakutia include:

- development tests to provide reliable operation of vehicles at negative $40^{\circ} \mathrm{C}$;

- $\quad$ taking measures to produce necessary legal papers, namely: River (sea) Register, documents for passenger transportation service, certification of vehicles and so on;

- $\quad$ providing grounds for subsidy of transportation within districts of arctic regions using all levels of budgets in the following ratio: municipal budget $-10 \%$, regional budget of the republic $-10 \%$, the Russian Federation federal budget $-80 \%$;

discovery of prospects of setting up a branch of a manufacturing plant in the Sakha Republic (Yakutia) for design improvement and testing of motor transport and other types of vehicles on the base of existing mechanical-repair factory in Neryungri within South-Yakutsk territory of priority development, and on the base of Zhatay ship repair and ship-building yard (amphibious snowmobiles). 
This would facilitate work of the plant manufacturing standard vehicle models eliminating the need to work out a more complex production process, which makes a vehicle manufacturing chain longer. Machines would be delivered to the specialized branch for re-equipment, where they would receive a complete "northern" upgrade.

The proposed model was discussed at a number of conferences. It suggests arranging experimental operation of snowmobile Aerosani Nerpa on the base of OOO ArcticSpetsMash together with the regional representative of Aerospetstrans in Yakutia, transportation unit of Federal Rescue Service and other parties interested in cooperation with Yakutsk North-Eastern Federal University, Yakutsk branch of Siberian State University of Water Transport, and Yakutsk city administration. The following areas with large number of river and lake crossings found in the extremely low-temperature regions could be used as testing sites: Abyysky (on the base of the existing federal budget-supported enterprise of Yakutia, Dorogi Arktiki), Bulunsky and UstYansky (on the base of municipal unitary enterprise MUP Direktsiya Edinogo Zakazchika) districts, as well as arctic regions of the Arctic Ocean coast, with subsequent use of vehicles there. Execution of these measures will improve transport accessibility of the arctic regions of Yakutia, mobility of population and quality of people's life, stimulating processes of social development of the region.

The authors proposed a conceptual solution of the problem of vehicle adaptation for operation under Arctic conditions and establishing a business system for shaping an infrastructure for certification and development tests of transport vehicles ensures faster rates of transport system upgrade and improvement in the Arctic.

\section{Acknowledgment}

The paper is prepared within implementation of the project on the instructions of the Ministry of Education and Science of the Russian Federation, No. 26.8327.2017/8.9P.

\section{References}

[1] T.P. Egorova "Organizacionnye problemy zavoza gruzov v arkticheskuyu zonu Yakutii”, Upravlenie ehkonomicheskimi sistemami: ehlektronnyj nauchnyj zhurnal, vol. 12 (72). pp. 51-55, 2014.

[2] P.Usenyuk, P.Hyysalo, J. Whalen, "Proximal design: Users as designers of mobility in the Russian North (Article)", Technology and Culture, Vol. 57, Issue 4, pp. 866-908, October 2016, DOI: 10.1353/tech.2016.0110

[3] T.P. Egorova, A.N. Myarin, A.M. Delakhova "Gosudarstvenno - chastnoe partnerstvo v razvitii mezhvidovoj konkurencii transporta na rechnyh perevozkah i perepravah Yakutii”, Proryvnye nauchnye issledovaniya kak dvigatel' nauki, vol.1, pp. 72-75, May 2017 [International scientific-practical conference Omega Science, p.271, 2017]

[4] A.N. Myarin "Vozrozhdenie klimaticheskih ispytanij modifikacij avtotransporta dlya Severa i Arktiki i snegobolotohodov v Yakutii", Zhurnal avtomobil'nyh inzhenerov, Vol. 1 (96), pp. 48-53, 2016.

[5] V.N. Leksin, B.N. Porfiryev "Specificities of spatial system transformation and strategies of the Russian arctic redevelopment under the conditions of climate changes" Economy of Region, vol.3, pp.641-657, 2017 DOI: 10.17059/2017-3-1

[6] V.N. Leksin, B.N. Porfiryev "Socio-economic priorities for the sustainable development of Russian arctic macroregion”, Economy of Region, vol.4, pp.985-1004, 2017 DOI: $10.17059 / 2017-4-2$

[7] N.Didenko, D.Skripnuk, O.Mirolyubova "Modeling the changes in global temperature due to pollution", SGEM2017 Conference Proceedings, Vol. 17, Issue 53, pp. 559-568, 2017 [7th International Multidisciplinary Scientific GeoConference SGEM, 29 June - 5 July, 2017] DOI: $10.5593 /$ sgem2017/53/S21.070

[8] N.I. Komkov, V.S. Selin, V.A. Tsukerman, E.S. Goryachevskaya "Problems and perspectives of innovative development of the industrial system in Russian Arctic regions", Studies on Russian Economic Development, vol.28, issue 1, pp.31-38, January 2017, DOI: $10.1134 /$ S1075700717010051

[9] G.F. Romashkina, N.I. Didenko, D.F. Skripnuk “ Socioeconomic modernization of Russia and its Arctic regions", Studies on Russian Economic Development, vol.28, issue 1, pp.22-30, January 2017 DOI: 10.1134/S1075700717010105

[10] V.N. Leksin, B.N. Porfiryev "Evaluation of the effectiveness of government programs of socioeconomic development of regions of Russia", Studies on Russian Economic Development, vol.27, issue 4, pp. 418-428, July 2016 DOI: 10.1134/S1075700716040109

[11] V.N. Borisov, O.V. Pochukaeva "Relationships between development factors of the Arctic Zone of the Russian Federation", Studies on Russian Economic Development, vol.27, issue 2, pp.159-165, March 2016 DOI: $10.1134 / \mathrm{S} 1075700716020040$

[12] E.V. Rytova, A.V. Kozlov, S.S. Gutman, I.M. Zaychenko "Analysis of the regulatory and legal framework of the socio-economic development in the far North Regions of Russia", Journal of Advanced Research in Law and Economics, vol. 7, issue 7, pp. 1828-1836, 2016 DOI: 10.14505/jarle.v7.7(21).30 